\title{
DEVELOPING ISLAMIC ECONOMICS AS A BODY OF KNOWLEDGE: ISSUES AND CHALLENGES
}

\author{
Hafas Furqani \\ Universitas Islam Negeri Ar-Raniry, Banda Aceh \\ Researcher at the International Sharah Research Academy for Islamic Finance \\ (ISRA) Malaysia
}

\begin{abstract}
Abstrak. Mengembangkan Ekonomi Islam sebagai Inti dari Ilmu Pengetahuan: Masalah dan Tantangan. Ekonomi Islam ditantang apakah itu dapat disebut disiplin dalam arti materi yang jelas, inti dari ilmu pengetahuan yang terorganisir dengan baik, metode untuk menilai teori dan akumulasi sistematis ilmu pengetahuan. Ekonomi Islam masih dalam tahap formatif untuk menjadi suatu disiplin. Sistematisasi bod nya pengetahuan masih dalam kemajuan. Banyak masalah mendasar perlu ditangani serius oleh komunitas ilmiah untuk ekonomi Islam menjadi disiplin yang sah. Tulisan ini mencoba untuk mengidentifikasi beberapa tantangan yang harus dijawab oleh ekonomi Islam komunitas ilmiah dalam effoert mereka untuk mengembangkan tubuh yang kuat dari pengetahuan ekonomi Islam. Memulai dari pandangan dunia Islam yang memberikan dasar-dasar dalam pemahaman kita tentang fenomena ekonomi, upaya yang harus dihukum untuk mengembangkan skema konseptual, metodologi untuk menilai dan mengevaluasi kerangka teori dan etika Islam. Jawaban untuk tantangantantangan akan menentukan arah ilmiah ekonomi Islam, ensurea pertumbuhan yang berkelanjutan pengetahuan dan mempercepat kecepatan proses evolusional ekonomi Islam menuju menjadi disiplin yang berbeda.
\end{abstract}

Kata Kunci: ekonomi Islam, pandangan Islam, ilmu pengetahuan.

Abstract. Developing Islamic Economics as a Body of Knowledge: Issues and Challenges. Islamic economics is challenged whether it can be called a discipline in the sense of having a clear subject-matter, well-organized body of knowledge, methodology to appraise theories and systematic accumulation of knowledge. Islamic economics is still in the formative stage to be a discipline. Systematization of its body of knowledge is still in the progress. Many fundamental issues need to be seriously addressed by the scientific community for Islamic economics to be a legitimate discipline. This paper attempts to identify several challenges to be answered by Islamic economics scientific community in their effoert to develop a solid body of knowledge of Islamic economics. Embarking from the Islamic worldview that gives foundations in our understanding of economic phenomena, efforts are to be put to develop the conceptual scheme, methodology to appraise and evaluate theory and Islamic ethics framework. The answer to those challenges will determine the scientific direction of Islamic economics, ensurea sustainable growth of knowledge and expedite the speed of the evolutional process of Islamic economics towards becoming a distinct discipline. 
Islamiconomic: Jurnal Ekonomi Islam

Vol.7 No.2 Juli - Desember 2016

Keywords: Islamic economics, Islamic worldview, foundations, discipline, knowledge accumulation

\section{Introduction}

Islamic economics as an organized body of knowledge is still in the process of development toward becoming a discipline. Its scientific elements, body of knowledge, methodology, are still in the development: stage and will continuously evolve to a more mature and sophisticated level in the future, provided all dimensions, including its philosophical foundations are given sufficient attention.

Being a new discipline, Islamic economics is challenged to eloquently present all dimensions that would make up a discipline, namely clear subject-matter, welldefined body of knowledge, methodology/-ies for theory appraisal and knowledge growth and accumulation. Nevertheless, this remains a challenge for Islamic economists, as there is no definitive answer on those dimensions is provided so far and consensus on the foundations of discipline is not yet attained.

The discipline is still at its formative stage and requires extensive intellectual efforts among Islamic economics scientific community to clarify, most importantly, the fundamental elements of science. This paper aims at identifying certain challenges to be seriously addressed by the scientific community in developing an Islamic economics discipline. Embarking from the Islamic worldview that gives basis in our understanding of economics phenomena, efforts is to be put to develop the conceptual foundations, key-terminologies, discipline conceptual scheme, methodology to appraise and evaluate theory and Islamic ethics framework.

\section{The Islamic Worldview and Islamic Economics}

Islamic economics is founded on Islamic worldview upon which we comprehensively see the existence and the interaction of all realities in it and economic phenomena whitin it. The Islamic worldview is the basis of a system of thought as well as a map to orient and explain economic phenomena, and from which we evaluate realities, and put forward prognoses and visions of the future. In the discipline contruction and development, the Islamic worldview will provide framework of thought, and objectives as well as a set of axioms and pronciples on 
Hafas Furqani: Developing Islamic Economics...

which that Islamic economics system of thought operates, shows direction and ensure progress and development of Islamic economics discipline.

The source of Islamic worldview is a revealed source (tanzil) namely the Qur'an (Berghout, 2007: 29). This source of explanation has a virtue to explain the truth and reality in totality based on certainty (yaqin) and not from a speculative or philosophical reasoning that is based on doubt (dzan) and gives a vulnerable and insecure worldview. Its scope of explanation that would take into consideration of this worldly life and the hereafter life, physics and metaphysics, visible and unseen realities, provides man a broader perspective of life and hence gives man a positive perspective of his current and future life direction.

The explanation of economic phenomena in Islamic economics is based on the Islamic worldview. The explanation would, ideally, more comprehensive as it covers in a holistic and unity perspective of explanation of the material, physical, mental, spiritual, and metaphysical dimension of realities with a socio-scientific explanatory power based on the revealed, rational and empirical sources of knowledge and having a balance and proper perspective of ethics/values. Nevertheless, this remains the challenge for Islamic economists to develop and offer a discipline of economics based on those perspective. Here, we outline some challenges that should be addressed in our attempt to develop a discipline of Islamic economics.

\section{Challenges I: The Foundations of Discipline}

Islamic economics discipline in an organized body of knowledge is a relatively new phenomenon (i.e., $20^{\text {th }}$ century at most). As a new discipline in understanding economy, Islamic economics is challenged to provide new outlooks, fresh solutions as well as better solutions in addressing economic problems and improving human well being.

Having a better worldview in understanding economic phenomena is not a guarantee that we can have a better economics and successfully address all problems/ challenges. All would depend on the foundations upon which our system of thought/ practice on and our scientific discipline is based on. In the latter, the main challenges are in developing the necessary elements for Islamic economics to be a discipline. This would include the ontological foundations (that would provide a basis 
Islamiconomic: Jurnal Ekonomi Islam Vol.7 No.2 Juli - Desember 2016

for delineating Islamic perspective in economics by clarifying Islamic conception of economic phenomena/ realities and hence developing the discipline conceptual foundation); epistemological (legitimate sources of knowledge, methodology of Islamic economics as well as criteria for theory appraisal and evaluations); and ethical foundations of discipline (the system of ethics and the incorporation of ethics into Islamic economics science and policy).

\section{Islamic Understanding of Economics Phenomena}

The Islamic worldview provides an outlook in understanding economic phenomena in an Islamic perspective. That perspective could answer the critics to the mainstream positivist/empiricist epproach for its simple and partial framework based on a materialistic conception of world with a reductionist outlook in understanding complex phenomena which is lilmited to sensible, observable and quantifiable realities. The positive-normative dichotomy propagated by the scientific method also worsens the situation and makes economic theory suffer 'lack of realism' and hence unable to explain realities as a whole (i.e individual, social, physical, metaphysical, observable and unobeservable realities) (Maki, 2001, Hands, 2008).

In mainstream economics there is a clash between ontological convictions of an economist and the apparent ontological implications of a theory held by this economist, that requires theory revision to realign ontology and theory. At present, as observed by Zeidan and Fonseca (2007: 177) in economics, there is an emerging consciousness to search for a new reference frame to understand economic reality properly.

Islamic economics should attempt to address that challenge. The elaboration of Islamic worldview in economic realm is potential to provide a broad basis in understanding of complex economic phenomena, events, agents, institutions, policy and practices by not separating the visible realm of phenomena, the body and the soul, the matters and the meanings, and this worldly-life and the after-life. The knowledge produced and theory appraised will reflect that perspective and will be evolving continuously through the process of orientation model of unification of knowledge in world-systems as derived from the primal source of Divine unity (tawhid) (Choudhury, 2000: 9). Tawhid (the unity of God which is the core of Islamic 
Hafas Furqani: Developing Islamic Economics...

worldview) provides orientation of the ultimate perspective in comprehending economic phenomena and in appraising theories based on that comprehension with a unity perspective between the individual and the society, the ideal and the reality, the absolute and the relative, the eternal and the temporal in the sacred and profane dimensions. In general, that framework of understanding economic phenomena derived from the Islamic worldview would be the basis in models building that lead to policy prescription and/or better comprehension of economic phenomena and of complex adaptive system to deal with economic processes in practical realms.

\section{Islamic Economics Conceptual Foundation}

After having perspectives/framework in understanding economic phenomena, the next challenge in the discipline construction process is, to develop an Islamic economics conceptual foundation. This would include the systematization of concepts (derived from the Islamic worldview) to be the foundations of Islamic economics.

The effort would be more than just attempting to answer to three foundational concepts of mainstream economics, namely scarcity of resources, pursuit of selfinterest and maximizing behavior of evonomic agents, to answering many fundamental questions such as the criteria of well-being, the macroeconomic goals as well as the microfoundations of Islamic economics to clarify the conception of the economic agent in Islam, his characteristics and behavioral criteria, etc., all of which would constitute the conceptual foundation of Islamic economics. The answer to those queries would determine the subject-matter, the scope and boundaries of discipline as well as the basis for further knowledge accumulation.

\section{Islamic Economics Key-Terminologies}

In the effort to develop conceptual foundation of discipline, Islamic economics needs to find 'key-terminologies' that would properly capture the messages of those concepts as well as reflect the Islamic worldview in viewing economic phenomena itself. The purpose is to construct a formal and logical representation of Islamic thought in economics.

In doing this, there are two possible approaches could be used. Firstly by reexamining, re-evaluating and redefining the key-terminologies of mainstream 
Islamiconomic: Jurnal Ekonomi Islam Vol.7 No.2 Juli - Desember 2016

economics within the Islamic scientific conceptual scheme before its adoption and utilization in Islamic economics. This approach has a pragmatic virtue by using already known terms/concepts in economics and substantially redefines them with an Islamic perspective. ${ }^{1}$ Secondly by proposing new key-terminologies to explain the Islamic understanding of economic phenomena. This approach has a genuine virtue of proposing a new conceptual framework that would reflect, Islamic worldview in understanding economic phenomena, clarify the distinctive feature of the nature, scope and objective of the discipline as well as provide Islamic scientific conceptual scheme where the Islamic economics science is operating. ${ }^{2}$

\section{Challenges II: The Epistemological Foundations}

Islamic economics is equipped with new sources of knowledge a part from intellectual reasoning and facts observation which is Divine revelation. Those sources of knowledge provide unique scientific basis of how to develop an Islamic economics discipline. The interaction of the three sources of knowledge will be translated into the body of knowledge of Islamic economics. The challenge in this regard is ini developing knowledge conceptual scheme and methodology to appraise theories in Islamic economics.

\section{Islamic Economics Conceptual Scheme}

The Islamic economics conceptual scheme is the general body of scientific nomenclature that constitutes a discipline with its distinctive goals, basic premises, and objects and methods of inquiry to be employed by Islamic economists (Bakar, 2006: 5). ${ }^{3}$ It is developed based on the 'general scientific conceptual scheme' which is developed earlier based on the Islamic worldview and Islamic epistemology in understanding knowledge ('ilm), truth, science, scientific statement, theory and method (Acikgenc, 1996b: 580). This would include the general body of knowledge of Islamic economics (substantive subject-matter of Islamic economics) and Islamic economic methodology to appraise and evaluate economic theories in Islamic economics (formal subject-matter of Islamic economics). This at the end would relate and form a composite body of knowledge, subject-matter, methodologies, and theories of Islamic economics that would make up a discipline. 
Hafas Furqani: Developing Islamic Economics...

Developing an Islamic economics conceptual scheme is very important for Islamization of economics takes place in a right way so that the knowledge borrowed must be evaluated within that scheme. For that purpose, Islamic economic conceptual foundation must be developed from its own sources (i.e., Islamic worldview) and using Islamic epistemology. A mere 'grafting' or 'transplanting' into it the Islamic principles/value while maintaining to work whitin the Western scientific conceptual scheme will produce conflicting results which according to Al-Attas (1979: 44) "are not altogether beneficial nor desirable." Unfortunately, in the absence of Islamic economic conceptual foundation, Islamic economists of today are still primarily working with the Western scientific conceptual scheme (neo-classical economic conceptual scheme) which is primarily developed by Western philosophers whitin the framework of their worldviews. Thus, forming knowledge and structuring discipline from Islamic worldview through Islamic economic conceptual scheme, is the primary criteria of an 'Islamic science of economics'.

We, therefore, believe for Islamic economics as a discipline to have progress in Islamic sense, efforts must be put to develop a well-formulated Islamic economics conceptual scheme as the 'environmental context' in which Islamic economics as a discipline will grow. In this endeavor, Hermansen (1996: 519) gives us insight that Islamic economists could actually re-view the classical heritage (turath) and derive some basic conclusions on 'earlier' conception of Islamic economics (or Islamic science in general), its basic assumptions and methodology in order to disclose the meta-disciplinary structure principles.

\section{Islamic Economic Methodology}

The discussion of methodology has a special place in the epistemological discussion especially in the context of establishing Islamic economic conceptual scheme for the development of discipline. The discussion of 'theory of knowledge' in epistemology would be specified and detailed further in the discussion of theory appraisal' in methodology. If the epistemology provides a bigger picture of source of knowledge and their justification for a discipline, methodology would provide guidelines and criteria of how to appraise and justify theories from those sources of knowledge. Methodology is nevertheless a reflection of epistemology. How we 
Islamiconomic: Jurnal Ekonomi Islam Vol.7 No.2 Juli - Desember 2016

conceive our source of knowledge would reflect the means (tools) developed to attain knowledge (theories) from those sources.

The sources of knowledge in Islamic epistemology are not limited on the facts as expose by law of nature or as experienced/showed by human behavior, but also including the divine revelation (al-wahy). The twin epistemological foundations of naql and 'aql; revelation and reason/universe would implicate the methodology to appraise theories as well as the criteria of truth to validate and invalidate theories in Islamic economics would be not identical with conventional mainstream economics.

The discussion of methodology of Islamic economics in chapter 8 would clarify those differences. Nevertheless, as an introduction in this epistemological discussion, it is suffice to say that methodological discussion is very important in developing an Islamic economic conceptual scheme (i.e., a nomenclature, environment and framework for developing Islamic economics discipline) and then Islamic economics body of knowledge in some respects. First, the methodology would clarify how to appraise theories and provide evaluation of the reliability of theories in Islamic economics (Blaug, 1992: xii). This task is very serious as Islamic economics at present is still lack in this methodological framework and hence depand heavily on conventional (neo-classical) methodological framework and criteria for theory appraisal and evaluation (Sardar: 1988; Alatas: 2006). Second, the progress of Islamic economics will depend on how good methodology could be offered and used to further progress the discipline. Knowledge accumulation will be contributed by methodology and discipline progress will be determined by the good handling of those accumulated knowledge. Methodology will play a role in knowledge production and knowledge accumulation to ensure that knowledge acquired is valid and legitimate. Third, the conventional scientific method criteria should be examined, analyzed, modified/replaced by Islamic scientific if deemed necessary in the light of Islamic objectives. The objectivist assumption (that there is an objective universe which can be explored, approximated, progressively and precisely by quantitative models), positivist assumption (that what is scientifically real must take as its basic data only from that which is physically observable) and reductionists assumption (that scientific explanation consist in explaining complex phenomena in terms of more elemental events and simple models) will need to be evaluated. A tawhidic 172 
Hafas Furqani: Developing Islamic Economics...

methodology that views realities in a harmony, integrity and unity perspective will be proposed and elaborated.

\section{Challenges III: The Ethical Foundations}

As a system of thought, economics is inherently infused by values found in or derived from a certain worldview. Our ontological perspective has great implications on how we see truth and reality, of how we conceive God, human beings, the universe and their relationship, and how we perceive life and its goals. Those ethical concepts which are derived from a particular worldview are translated and incorporated into the subject matter of economics especially that dealing with human behaviour. Therefore, different worldviews might create not only 'philosophical differences' of economic thought, but also 'behavioural differences' and 'theoretical differences' and 'policy differences' appraised there on.

Hence the claim of scientification process of economics to be a purely positivist and objective science, by screening it from value-blas, irrational-elements or personal-judgements, so that could be accepted by and applied to all societies, is a myth. Instead, that process screening values into a particular value framework that is in line with a particular worldview, justifying that value framework to achieve certain visions or goals. The claimed neutralization process of ethics in economics is actually not a process of extricating 'all' ethical values from economics, but a process of 'selecting' preferable ethical posistions based on certain worldview of realities of materialism and secularism and inserting them into economic theories.

Economic ethics as propagated in the mainstream neoclassical economics, from the Islamic point of view is problematic at least in two senses; in the nature and scope of application. Ethics in the secular tradition is purely defined in the mundane and material dimension. There is a systematic effort in the Western experience to replace 'divine ethics' (i.e., a religious based ethics with point of reference is in a transcendent personal Creator) by 'human arrangement ethics' (which is rooted in human narratives and experiences). This is done by (1) deligitimizing the role of religion in establishing values and its standard; and (2) autonomization of ethics whereby values can be established by human himself through his reasoning and experience (Hunt, 2002: 15$) \cdot 4$ 
Islamiconomic: Jurnal Ekonomi Islam Vol.7 No.2 Juli - Desember 2016

Apart from secularization of ethics, ethical formulation in economics has also been marked by the scientism spirit that scrutinizes ethics to be an observable and measurable ethics. While seculariation requires ethics that is purely profane and mundane, scientism/scientification scrutinizes it further by requiring ethics that is sensible, observable and measurable. The two processes would at the end divorcing science from ethics and ethics from science. This implicates to the reduction of moral and/or spiritual component of social and/or natural reality to its material realm and effect. The scientific is equated with the reliably measurable, and hence excluding a vast realm of human concern of moral, spiritual and transcendental values which are mostly discounted as subjective and metaphysics which cannot be verified and measured therefore it is meaningless.

With the secularism and scientism spirit, separation/marginalization has been made between the mundane and divine, profane and sacred, material and spiritual, observable and non-observable values. The concepts of perfect knowledge, perfect completition, rational expectation, invisible hand, free market, market efficiency, are the example of economic concept enshrined by that spirit. Likewise, the concepts of self-interest and utility maximization that constitute individual rationality are develeped based on assumptions that reflect certain values. They are not really descriptive in nature and have been falsified by many practices in human history.

Moreover, those concepts have also been internally and externally criticized mainly due to their inadequacy to properly describe the real practices (lack of ontological fit), their inability to properly guide human to achieve the ultimate goal of life and they are actually not really describing proper ethics for human being or bypassing the actual man with a fuller perspective of behavior, potensials and motives (Sen, 1977, 1990; Davis, 2003). ${ }^{5}$ Therefore, the mainstream neoclassical conception of macro economics goals as well as microfoundation of economics has been challenged and some changes have been proposed in economics discourse.

1.1 Developing Islamic Economics Ethics

Islamic economics attempts to develop its own conceptions and offers some new perspectives of ethics in understanding economic phenomena, economic goals as well as the behavior of representative economic agent. Economic ethics in Islam is structured based on the Qur'anic weltanschauung of ethics. The Islamic economic 174 
Hafas Furqani: Developing Islamic Economics...

ethics is developed within the Qur'anic ethical system. The Qur'anic ethos makes up an Islamic value system that Islam intends to base its system of economics on. Those value-patterns embodied in the Qur'an and the Sunnah is holistic as it does not only deal with the earthly life but also has the notion of afterlife, not only concern with material aspect but also spiritual dimension.

This ethical system of economics is put forward as parts of the larger ethical system since economics in Islam is considered as part of 'religion' whereby all business activities, wealth creation, economic development, wealth distribution, human welfare are also the 'business of religion'. Secularization (marginalizing the role of religion in scientific enterprise and from the public arena) is therefore not acceptable as Islam holds that ethics is not only interrelated with religion, but they are inseparable and are built entirely upon it (al-Attas, 1993; Izutsu, 2004). Religious values which become part of internal individual's consciousness are the motivating forces for human beings in his effort to achieve happiness and wellbeing (i.e., material achievement and spiritual attainment). ${ }^{6}$

The axiological study in Islamic economics attempts to bring back ethics as taught by religion in theoretical and practical aspects. The neglect of moral, spiritual as well as metaphysical elements as propagated in mainstream economics should be explicated. That narrow perception of ethics (as defined in secularist or positivist ethics) has brought worse consequence in human development. At micro-level the nature of individual has been reduced into a half-person characterized by a selfinterest motive. At a macro level we have seen the society inequalities as well as ecological destruction due to human selfish behavior.7 This is then followed by developing Islamic ethics in economics and incorporating those ethics into the body of science characterized Islamic economics as a discipline. The actualization (objectification) of ethics by Islamic man in his economic pursuit will be the basis in our objective evaluation of the reliability of Islamic economic theory and policy.

Ethics would be adopted on instrinsic grounds rather than as a matter of expediency in theory appraisal and practical application with the purpose of creating an economy with an ethical and spiritual superiority. As a science, Islamic economics is a self-consciously value-oriented discipline which rejects the idea that economic theories and policies can take place in a climate of positivistic objectivity and of 
Islamiconomic: Jurnal Ekonomi Islam Vol.7 No.2 Juli - Desember 2016

complete value neutrality (Ahmad, 1979: 226 and Esposito \& Voll, 2001: 52), and at the same time, insists on incorporating ethics and religious insights into its theory as well as policy. Islamic economics, in this regard, makes its ethico-religious connections explicit at the very outset (Naqvi, 1994: xvii). ${ }^{8}$ This characterizes Islamic economics to the other economics, as Nienhaus (2000: 86) observes

while Western economists have tended to withhold value judgements and have only begun to return to the treatment of normative questions in the last few years, Islamic economics, in contrast, has always defined itself as a science which makes explicit value judgments and links them to the findings of positive economics

This unique position of Islalmic economics, i.e., its commitment to ethics, will not only able to provide a framework for a unique economics since these principles are unique to the worldview of Islam, but they are in fact, just and comprehensive ethics when they are implemented would create a society which has all the hallmarks of justice and equity, sharing and cooperatio, as well as economic dynamism and growth (Sardar, 1988: 200). They are, as we will show, meanigful moral philosopy that could be the basis of ethical foundation of economics and framework to produce the best social structure (Naqvi, 1994: xvii). ${ }^{9}$

If the scientification process in conventional economics intends to screening religious, metaphysical, spiritual and unobservable values from economics, the scientification process in Islamic economics intends to incorporate the derived ethical principles from the Qur'an and Sunnah in Islamic economics theory and analysis and to actualize the in the behavior of Islamic man. Islamic economics, as a science is going to intertwine the ethical considerations developed in Islamic framework with theoretical analytical thought and practical economy and policies. The challenge in the scientification of Islamic economic ethics is to produce a set of workable normativeideals that would create a better individual and society in realities. While there will be no differences among Islamic scholars in general and Islamic economists in particular on the need of ethico-religous to be the foundation of Islamic economic analysis, the differt approach and method to appraise and apply those ethical principles in an economic theory or policy can be seen in scholars' works. 
Hafas Furqani: Developing Islamic Economics...

In addition, deriving values to be incorporated in economic analysis is not an easy task, and indeed, not many Islamic economists put considerable efforts on this issue. Therefore, although consensus has been achieved of the need to incorporate values in Islamic economic analysis, the works that are designated for such attempts, either in the ethical conception or formulating ethical theories in economic modeling, are not many. This ethics inclusion in economics is still one of challenges $\mathrm{n}$ developing Islamic economics as a disciplin. The effort is not only to present the Islamic point of view about economic processes and to highlight its distinctive normative character in relation to other ideologies, namely capitalism or socialism, but most importantly, as Naqvi (1994: xx) suggest, "in expanding, broadening the science of economics which has been narrowed and enlightening proper values which has been distorted", and also in producing the real society who will apply all Islamic ideals (precepts) in practices that would create them to be the best exemplary society as Hofmann (1993: 101) puts "an Islamic economic system in an ideal sense must be preceded by an Ummah in an ideal sense."

\section{Conclusion}

This paper discusses some challenges to be addressed in our attempt to construct a discipline of Islamic economics characterized by a clear subject-matter, well defined body of knowledge, methodology/-ies to appraise theories and systematic knowledge accumulation. Embarking from the Islamic worldview that provides foundations and basis for Islamic economics to operate and grow, we elaborate some importance dimensions in the discipline foundations that include the Islamic understanding of economic phenomena, Islamic economics conceptual foundation, Islamic economics key-terminologies, Islamic economics conceptual scheme, Islamic economic methodology and Islamic economic ethic.

The scientific community responses to those challenges are needed to clarify the Islamic perspectives and hence a distinct discipline of Islamic economics could be established. In this attempt, Islamic economists could benefit from the existing economics of how the paradigm is formed and consensus attained in all dimensions of discipline, while resorting from our own sources and intellectual legacy (turath) and 
Islamiconomic: Jurnal Ekonomi Islam Vol.7 No.2 Juli - Desember 2016

having a visionary and value-scrutinization of conventional body of knowledge prior its acceptance in Islamic economics.

Strong efforts, creativity and innovation should always be attempted by Islamic intellecctual community to determine the scientific direction of Islamic economics, to ensure a sustainable growth of knowledge and to expedite the speed of the evolutional process of Islamic economics towards becoming a distinct discipline. A complete and solid foundation of Islamic economics discipline is not an instant-made thing. It requires a massive intellectual efforts and commitment and a long-continuous process.

\section{References}

Acikgenc, Alparslan. (1996b). Toward an Islamic concept of philosophy: A response to the modernists. In Sharifah al-Attas (ed.), Islam and the challenge of modernity (pp.535-589). Kuala Lumpur: ISTAC.

Ahmad, Khurshid. (1979). Economic Development in an Islamic Framework. In Khurshid Ahmad and Zafar Ishaq Ansari (eds.). Islamic Perspective (pp. 223240). Leicester, England: The Islamic Foundation.

Alatas, Syed Farid. (2006). Islam and the science of economics. In Ibrahim M. Abu Rabi' (ed.), The blackwell companion to contemporary Islamic thought (pp. 587606). USA: Blackwell Publishing.

Al-Attas, Syed Muhammad Naquib. (1979). Preliminary thoughts on the nature of knowledge and the definition and the aims of education. In Syed Muhammad Naquib Al-Attas (ed.), Aims and objectives of Islamic education (pp. 19-47). Jeddah: King Abdul Aziz University.

Al-Attas, Syed Muhammad Naquib. (1993). Islam and secularism. Kuala Lumpur: ISTAC.

Arif, Muhammad. (1987a). The Islamization of knowledge and some methodological issues in paradigm building: The general case of social science with a special focus on economics. AJISS, 4 (1), 51-71.

Bakar, Osman. (2006). Classification of knowledge in Islam: A study in Islamic philosophies of science. Kuala Lumpur: ISTAC. 
Hafas Furqani: Developing Islamic Economics...

Berghout, Abdelaziz. (2007). Toward an Islamic framework for worldview studies: Preliminary theorization. AJISS, 24 (2), 22-43.

Blaug, Mark. (1992). The methodology of economics: or how economists explain $\left(2^{\text {nd }}\right.$ edn.). Cambridge: Cambridge University Press.

Choudhury, Masudul Alam. (2000). The Islamic Wordlview: Socio-Scientific Perspective. London: Kegan Paul International ltd.

Davis, John B. (2003). The theory of the individual in economics: identity and value. London: Routledge.

Engelhardt, H. Tristam. (2004). Taking moral difference seriously: Morality after the death of God. In Douglas Farrow (ed.), Recognizing religion in a secular society: Essays in pluralism, religion, and public policy. Canada: McGill-Queen's University Press.

Esposito, John L and Voll, John O. (2001). Makers of contemporary Islam. Oxford: Oxford University Press.

Galbraith, John Kenneth. (1983). The Anatomy of Power. Boston, USA: Houghton Miffin Company.

Hands, D. Wade. (2008). Philosophy and economics. In Steven Durlauf and Lawrence Blume (eds.), The New Palgrave Dictionary of Economics (vol. 2, pp. 410-420). New York: Palgrave - Macmillan.

Hermansen, M. K. (1996). Modernity and religious worldviews: The challenge of classical Islamic religious thought for contemporary Muslim intellectuals. In Sharifah Shifa al-Attas (ed.), Islam and the challenge of modernity (pp. 535-589). Kuala Lumpur: ISTAC.

Hofmann, Murad. (1993). Islam: the Alternative. UK: Garnet Publishing Ltd.

Hunt, S. J. (2002). Religion in Western society.Cambridge: Cambridge University Press.

Izutsu, Toshihiko. (2004). Ethico-Religious Concepts in the Qur'an. Kuala Lumpur: Islamic Book Trust.

Maki, Uskali. (2001a). The economic worldview: Studies in the ontology of economics. Cambridge, UK: Cambridge University Press.

Naqvi, S. N. H. (1994). Islam, economics and society. London: Kegan Paul International. 
Islamiconomic: Jurnal Ekonomi Islam

Vol.7 No.2 Juli - Desember 2016

Nienhaus, Volker. (2000). Islamic economics: Dogma or science. In Kay Hafez (ed.),

The Islamic World and the West (pp. 86-99). (Mary Ann Kenny, trans.) Leiden: Brill.

Qutb, Sayyid. (1991). The Islamic concept and its characteristics. (Mohammed Moinuddin Siddiqui, Trans.). Plainfield, USA: American Trust Publication.

Sardar, Ziauddin. (1988). Islamic futures: The shape of ideas to come. Kuala Lumpur: Pelanduk Publication.

Sen, Amartya. (1977). Rational Fools: A Critique of the Behavioural Foundations of Economic Theory. Phillosophy and Public Affairs, 6 (4), 317-344.

Zeidan, Rodrigo and Fonseca, Maria. (2007). Metaphors and method: Epistemological considerations on complexity science. In Carlos Geshenson, Diederik Aerts and Bruce

Edmonds (eds.). Worldviews, science and us: Philosophy and complexity (pp. 173-180).

Singapore: World Scientific Publication.

\section{End Notes:}

\footnotetext{
${ }^{1}$ In the literature it is done by substantially redefine the existing terms in an Islamic economics and in some cases by putting 'Islamic' prefix to those terms, such as Islamic utility, Islamic rationality and etc.

${ }^{2}$ We should however note that not all economic terminologies should be replaced by new 'Islamic' terminologies, only those terminologies that would constitute the Islamic economic scientific conceptual scheme (i.e., the Islamic context for discipline of economics to operate) needs to be replaced. We opines that the concept such as self-interest, utility maximization and rationality behavior could be replaced by for example huquq (right and obligation, self's, others' and nature's interest) as the basis of individual behavior, maslahah (benefit and harm) as the objective in making decisions and choices and taqwa (God's consciousness) behavior as the virtue of individual economic man. Many other key concepts in mainstream economics could be replaced or transforms in a new Islamic terminologies.

${ }^{3}$ Arif (1987: 56) calls it as the establishment of 'philosophical foundations of discipline' from where we can embark to 'paradigm building' that is the stratification of 'primary concepts' in Islamic economics discipline.

${ }^{4}$ In the practical ethics, the effort has two practical postulates: (1) the agnostic moral postulate, where one acts and speaks as if there were no God, and (2) the ecumenical religious postulate where one acts and speaks as if religious concerns did not involve matter of fact, as if religion were not a matter regarding which one can be right or wrong and no claims regarding transcendent truth are approved (Engelhardt, 2004: 130).

${ }^{5}$ The Islamic critics of those values as well as Islamic alternative will be discussed in chapter 10 on "The Microfoundation of Islamic Economics: The Core Values".

${ }^{6}$ Therefore, the history of ethics in Islam shows that while there are differeces of opinions, this never led the scholars to detach ethics from religion as promoted by secularism. This is also true even in modern times as observed by Galbraith (1983: 175) the triumph of secularization of ethics in the West marked by the diminishing role and power of religion, might not be relevant to Islam because "for Moslems personality remains much more important; it is manifested by the stronger presence of both God and the Prophet and by prayers for their intercession... and Islamic organization has a far greater internal discipline and consequent external effect...as a result, Islam remains a much stronger source of power than that available in the even more deeply divided Christian religion."

${ }^{7}$ Therefore, as Nasr (1994: 37) rightly points out, effort to Islamize modern economics and develop a distinct discipline of Islamic economics must be initiated from studying its philosophical foundations from the
} 
Hafas Furqani: Developing Islamic Economics...

Islamic point of view in order to reveal for Muslims exactly what is the value system upon which it is based and how this value system opposes, complements, or threatens the Islamic value system.

${ }^{8}$ The problem with present economics as observe by Hazim Shah (2008: 99) is that while ethics is gained recognation, but it is subsumed to the economic logics and then valued at the material and financial goal. The ideology of economic growth remain mainstream in economic goals so to spenk of cultural differences, religious tolerence, international ethics, seem to speak the language of the ineffectual and idealistic, which would eventually be subsumed under economic logic.

${ }^{9}$ Sayyid Qutb (1991: 1) in this regard is very confidence this could be achieved since "Islamic din was revealed in order to initiate a special kind of community, unique and distinctive, namely an ummah that came to lead mankind, to establish the way of Allah on earth, and to save people from the misery brought about by misguided leadership, erroneous ways, and false concepts". Ahmad (1979: 226) also points out "the major contribution of Islam lies in making human life and effort purposive and value-oriented. The transformation it seeks to bring about in human attitudes and paripassu in that of the social sciences is to move them from a stance of pseudo value-neutrality towards open and manifest value-commitment and value-fulfillment." 
Islamiconomic: Jurnal Ekonomi Islam Vol.7 No.2 Juli - Desember 2016 